\title{
PERLINDUNGAN HUKUM EKSPRESI BUDAYA TRADISIONAL DALAM BINGKAI REZIM HAK CIPTA*
}

\author{
Oleh : \\ Anak Agung Sinta Paramisuari** \\ Sagung Putri M.E. Purwani ${ }^{* * *}$ \\ Program Kekhususan Hukum Bisnis Fakultas Hukum \\ Universitas Udayana
}

\begin{abstract}
Indonesia has so many Traditional Culture Expression (TCE) which has given many advantages for their arts by the social community. But, because the lack of knowledge by the social community has causing many claims for their TCE. The claims happen because of the insufficient legal protection of the Law Number 28, 2014 about Copyright. The issue on this writing related to the legal protection regulation of Traditional Culture Expression in Indonesia as well as mastery of copyright by the Nation for the TCE. This writing is based on analytic descriptive normatic law research method by using statue approach and counting on secondary data as the main source data. The result of this writing is, the preventive protection of TCE in Indonesia is contained in the Act Number 28, 2014 about Copyright on article 38. Mastery of copyright hold by the nation for TCE as stated on Article 38 Law of Copyright done by automatic mechanism directly by the Nation, and by the mentioning of Nation has not been able to deliver clear definition about the Nation itself. To overcome this issue, it is advised for the government to reinforce the statement in Article 38 Copyright Law, to clarify the definition of the word Nation in Article 38 Copyright Law, and also nevertheless, the government should give protection for the social community rights as the holder of TCE as well as protecting the existency of TCE itself.
\end{abstract}

${ }^{*}$ Penulisan karya ilmiah yang berjudul "Perlindungan Hukum Ekspresi Budaya Tradisional dalam Bingkai Rezim Hak Cipta” ini merupakan ringkasan diluar skripsi.

** Penulis pertama adalah Anak Agung Sinta Paramisuari, Mahasiswi Fakultas Hukum Universitas Udayana,e-mail:junk_sinta@yahoo.com.

*** Penulis kedua adalah Sagung Putri M.E. Purwani, S.H., M.H. selaku Pembimbing Akademik penulis pertama di Fakultas Hukum Universitas Udayana, e-mail: sg_putri@yahoo.co.id. 
Key Words : Protection, Traditional Culture Expression (TCE), Copyright.

\begin{abstract}
ABSTRAK
Indonesia yang kaya akan ekspresi budaya tradisional (EBT) memberikan banyak keuntungan atas berbagai karya seni yang dihasilkan oleh masyarakat adat. Namun, kurangnya pengetahuan yang dimiliki oleh masyarakat adat menyebabkan banyak terjadi kasus klaim tentang EBT. Klaim itupun dapat terjadi akibat perlindungan hukum tentang EBT yang diatur dalam UU No. 28 Tahun 2014 tentang Hak Cipta belum dapat melindungi EBT secara maksimal. Adapun permasalahan dalam penulisan ini berkaitan dengan pengaturan perlindungan hukum Ekspresi Budaya Tradisional di Indonesia serta penguasaan hak cipta yang dipegang oleh negara terhadap (EBT). Dalam penulisan ini menggunakan metode penelitian hukum normatif yang bersifat deskriptif analitis dengan menggunakan jenis pendekatan perundang-undangan dan mengandalkan data sekunder sebagai sumber data utama. Hasil dari penulisan ini adalah perlindungan preventif dari EBT di Indonesia terdapat dalam UU No. 28 Tahun 2014 Tentang Hak Cipta yang terdapat dalam ketentuan pasal 38. Kemudian adapun penguasaan hak cipta yang dipegang oleh Negara terhadap EBT sebagaimana yang terdapat dalam ketentuan pasal 38 UUHC ini dilakukan dengan mekanisme otomatis secara langsung oleh Negara, dan adapun makna kata Negara yang terdapat didalamnya belum memberikan pengertian yang jelas mengenai kata Negara yang terdapat didalamnya. Untuk mengatasi hal tersebut disarankan agar pemerintah segera merealisasikan ketentuan pasal 38 UUHC, kemudian memberikan kejelasan definisi kata Negara dalam pasal 38 UUHC, serta hendaknya pemerintah memberikan ruang perlindungan terhadap hak masyarakat adat sebagai pemegang EBT disamping melindungi keberadaan EBT itu sendiri.
\end{abstract}

Kata Kunci : Perlindungan, Ekspresi Budaya Tradisional (EBT), Hak Cipta. 


\section{PENDAHULUAN}

\subsection{Latar Belakang Penulisan}

Ekspresi Budaya Tradisional (EBT) yang pada awalnya disebut dengan istilah folklor atau folklore merupakan warisan budaya yang dimiliki masyarakat adat yang keberadaannya wajib dilindungi, sebab bagi masyarakat adat folklor merupakan salah satu aset yang sangat berharga sebagai pemberi identitas kepada sebagian masyarakat dari suatu Negara. ${ }^{1}$ Namun, dengan diundangkannya UU No. 28 Tahun 2014 tentang Hak Cipta (UUHC 2014) istilah folklore atau folklor ini diganti dengan istilah Ekspresi Budaya Tradisional (EBT).

Indonesia yang kaya akan EBT mempunyai potensi ekonomi yang menjanjikan terutama terkait dengan industri pariwisata dan industri ekonomi kreatif. Pulau Bali misalkan, dimana kehidupan masyarakat Bali yang kental akan seni menjadi satu aspek yang sangat menonjol dalam kehidupan sehari-hari, karena sebagian besar dari wujud hidup keseharian itu dibarengi dengan penyertaan unsur-unsur benda, aktivitas, dasar filosofis yang bernilai seni. ${ }^{2}$ Seiring dengan perkembangan zaman, aktivitas tersebut kemudian berkembang menjadi suatu industri pariwisata yang bermanfaat sebagai sumber pendapatan ekonomi daerah dan menjadikan Bali dikenal seluruh dunia. Di bidang industri ekonomi kreatif terutama produk kerajinan berbasis EBT seperti, kerajinan batik, seni ukir kayu, perak, tenun adalah produk yang mempunyai sumbangan yang cukup besar untuk meningkatkan devisa negara. Akan tetapi, kurangnya pengetahuan yang dimiliki oleh masyarakat Indonesia mengenai hak cipta, menyebabkan

1 M. Munandar Sulaeman, 1995, Ilmu Budaya Dasar, Suatu Pengantar, PT. Eresco, Jakarta, h. 43.

2 I Gde Pitana Dkk, 1994, Dinamika Masyarakat dan Kebudayaan Bali, BP, Denpasar, h. 121. 
banyak terjadi kasus terkait klaim oleh pihak asing dari pada EBT yang seharusnya dimiliki oleh Negara Indonesia. Salah satunya seperti kasus Ketut Deni Aryasa, perajin perak asal Bali yang dituding menjiplak salah satu motif perusahaan perak milik asing, PT. Karya Tangan Indah (PT. KTI). Adapun motif yang digunakan Deni Aryasa adalah milik kolektif masyarakat di Bali, yang sudah ada sejak dulu. Ia dituding meniru dan menyebarluaskan motif fleur atau bunga (salah satu motif tradisional Bali yang hampir dapat ditemui pada seluruh ornamen seni di Bali). Ironisnya, motif ini telah dipatenkan pihak asing di Direktorat Hak Cipta, Direktorat Jenderal HKI Republik Indonesia pada tahun 2006 dengan nomor 030376. Pada surat keputusan Ditjen Haki, tertulis pencipta motiffleur adalah Guy Rainier Gabriel Bedarida, warga Prancis yang bermukim di Bali. Sedangkan pemegang hak cipta adalah PT.KTI milik pengusaha asal Kanada, John Hardy. ${ }^{3}$ Saat ini diperkirakan lebih dari 1.800 motif perhiasan perak Bali sudah diklaim hak ciptanya oleh pihak asing. Sebagai contoh motif produk kerajinan yang didaftarkan oleh pihak asing adalah motif Keplak yang berasal dari Bali, yang kini namanya diubah menjadi dot motive dan diklaim sebagai hasil ciptaan pengusaha perak asing. ${ }^{4}$ Kondisi tersebut tentunya merugikan masyarakat adat khususnya Bali, karena pemanfaatan pengetahuan tradisonal dan ekspresi budaya tradisional dengan mudah dapat diklaim sebagai domein pihak lain yang lebih dulu mempublikasikan dan mendaftarkannya. Terkait dengan hal tersebut, penting halnya untuk melindungi EBT yang dimiliki oleh Indonesia. Adapun

3 Kompas.com, 2008, "Weleh... Perajin Bali Malah Dituding Menjiplak", URL: https://nasional.kompas.com/read/2008/09/12/14474846/weleh.peraji n.bali.malah.dituding.menjiplak, diakses tanggal 27 Oktober 2018.

${ }^{4}$ International Law in News, Berebut Hasil Kreasi Pengrajin Perak Bali, Jurnal Hukum Internasional, Volume 6 Nomor 1 Oktober 2008, h. 158. 
perlindungan EBT di Indonesia diatur dengan UUHC 2014 yang merupakan salah satu rezim dari hukum Kekayaan Intelektual (KI). ${ }^{5}$ Adapun pasal yang mengatur khusus tentang EBT terdapat dalam Pasal 38. Pada pasal tersebut dikatakan bahwa pemegang hak cipta atas ekspresi budaya tradisional dipegang oleh Negara. Maka dari itu, sebagai salah satu upaya perlindungan hukum yang tercantum dalam peraturan perundang-undangan tersebut adalah Negara wajib menginventarisasi, menjaga, dan memelihara EBT. Namun, adapun makna "Negara" yang terdapat pada pasal 38 tersebut belum jelas. Apakah makna Negara yang dimaksud itu dalam lingkup pemerintahan provinsi (gubernur), ataupun dalam lingkup kabupaten atau/kota (bupati/walikota). Hal ini menunjukkan kekaburan norma, karena terdapat makna "Negara" yang belum jelas pada pasal 38 tersebut.

\subsection{Rumusan Masalah}

Berdasarkan pemaparan latar belakang diatas, adapun masalah yang diangkat yaitu :

1. Bagaimanakah pengaturan perlindungan hukum Ekspresi Budaya Tradisional di Indonesia?

2. Bagaimanakah penguasaan hak cipta yang dipegang oleh negara terhadap Ekspresi Budaya Tradisional?

\subsection{Adapun Tujuan dari Penulisan Jurnal ini, yaitu :}

1. Untuk mengetahui pengaturan perlindungan hukum Ekspresi Budaya Tradisional di Indonesia;

2. Untuk mengetahui penguasaan hak cipta yang dipegang oleh negara terhadap Ekspresi Budaya Tradisional.

${ }^{5}$ Ida Ayu Sukihana, I Gede Agus Kurniawan, 2018, Karya Cipta Ekspresi Budaya Tradisional: Studi Empiris Perlindungan Tari Tradisional Bali di Kabupaten Bangli, Jurnal Magister Hukum Udayana, Vol.7 No.1 Mei 2018, Denpasar, h. 52. 


\section{ISI MAKALAH}

\subsection{Metode Penulisan}

Penulisan ini menggunakan metode penelitian hukum normatif, karena metode penelitian hukum normatif merupakan suatu prosedur penelitian ilmiah yang berfungsi untuk menemukan kebenaran berdasarkan logika keilmuan hukum dari sisi normatif sehingga mampu untuk menjelaskan perlindungan hukum terhadap keberadaan Ekspresi Budaya Tradisional dalam bingkai rezim hak cipta. ${ }^{6}$ Maka untuk menjawab isu hukum yang terdapat dalam karya ilmiah ini, penulis menggunakan jenis pendekatan perundang-undangan dengan mengandalkan data sekunder sebagai sumber data utama. Penelitian ini juga dapat dikatakan bersifat deskriptif analitis. Dikatakan deskriptif karena menggambarkan permasalahan yang dibahas, menggunakan analitis karena peraturan hukumnya yang akan dianalisis untuk menjawab permasalahan yang diajukan dalam penelitian ini.

\subsection{Hasil dan Analisis}

\subsubsection{Pengaturan Perlindungan Hukum Ekspresi Budaya Tradisional (EBT) di Indonesia}

Indonesia sebagai negara kepulauan yang memiliki beraneka ragam seni dan budaya tradisional yang diciptakan oleh masyarakat adat sebagai penunjuk identitas sosial dan budaya berdasarkan standar dan nilai - nilai yang tumbuh dan berkembang didalam masyarakat perlu untuk mendapatkan perlindungan hukum, mengingat betapa pentingnya EBT bagi Negara Indonesia khusnya bagi masyarakat adat sebagai penunjuk identitas Negara, dimana terdapat hak masyarakat tradisional

6 Johny Ibrahim, 2011, Teori dan Metodologi Penelitian Hukum Normatif, Bayu Media, Malang, h. 57. 
didalamnya yang perlu untuk mendapatkan perlindungan hukum sebagai bentuk penghormatan dan wujud penghargaan terhadap hak masyarakat tradisional atas karya-karyanya. Perlindungan mengenai hak masyarakat atas kekayaan budaya tradisional merupakan salah satu kewajiban pemerintah, yang salah satunya merupakan kewajiban dari konstitusional Negara berdasarkan Amandemen Undang-Undang Dasar NRI Tahun 1945, dimana Negara menghormati kebudayaan tradisional dari masyarakat adat sebagai bagian dari kebudayaan nasional Negara Republik Indonesia ditengah peradaban dunia dengan menjamin hak-hak masyarakat dalam mengembangkan nilai-nilai budayanya, sebagaimana yang telah termaktubkan di dalam pasal $18 \mathrm{~B}$ ayat (2), pasal 28 I ayat (3), dan pasal 32 ayat (1) UUD NRI Tahun 1945.

Hak Kekayaan Intelektual adalah hak atas kekayaan yang berasal dari karya intelektual manusia, yaitu hak yang berasal dari kreatifitas daya pikir manusia yang diekspresikan dalam berbagai bentuk karya yang bermanfaat serta berguna untuk menunjang kehidupan. ${ }^{7}$ Melalui perspektif ini, instrumen hukum yang melindungi EBT berada dibawah naungan rezim hak cipta. Hal ini terlihat dengan dimasukkannya EBT dalam UU No. 28 Tahun 2014 Tentang Hak Cipta, karena hak cipta merupakan salah satu cabang dari hak kekayaan intelektual yang memasukkan EBT kedalam ranah seni, sastra, dan ilmu pengetahuan. ${ }^{8}$

Hak Cipta adalah hak eksklusif pencipta yang timbul secara otomatis berdasarkan prinsip deklaratif setelah suatu ciptaan diwujudkan dalam bentuk nyata tanpa mengurangi pembatasan

7 Ni Ketut Supasti Dharmawan Dkk, 2017, Hak Kekayaan Intelektual (HKI), Deepublish, Yogyakarta, h.19.

8 Arif Lutviansori, 2010, Hak Cipta dan Perlindungan Folklor di Indonesia, Graha Ilmu, Yogyakarta, h. 99. 
sesuai dengan ketentuan peraturan perundang-undangan. (Pasal 1 angka 1 UUHC). Di dalam UUHC juga mengatur mengenai EBT yang terdapat pada ketentuan pasal 38 ayat (1), (2), (3), dan (4). EBT menurut penjelasan pasal 38 ayat (1) UUHC adalah yang mencakup salah satu atau kombinasi bentuk ekspresi sebagai berikut :

1. Verbal tekstual, baik lisan maupun tulisan, yang berbentuk prosa maupun puisi, dalam berbagai tema dan kandungan isi pesan, yang berbentuk karya sastra ataupun narasi informatif;

2. Musik, mencakup antara lain, vokal, instrumental, atau kombinasinya;

3. Gerak, mencakup antara lain, tarian;

4. Teater, mencakup antara lain, pertunjukan wayang dan sandiwara rakyat;

5. Seni rupa, baik bentuk dua dimensi maupun tiga dimensi yang terbuat dari, berbagai macam bahan seperti kulit, kayu, bambu, logam, batu, keramik, kertas, tekstil, dan lainlain atau kombinasinya; dan

6. Upacara adat.

Negara sebagai otoritas tertinggi, dan pemerintah daerah sebagai representasi negara dalam perlindungan dan pengaturan EBT dapat mencegah adanya pemanfaatan komersialisasi oleh pihak asing tanpa seizin negara sebagai pemegang Hak Cipta. Pada pasal 60 ayat (1) UUHC disebutkan, Hak Cipta atas ekspresi budaya tradisional yang dipegang oleh negara sebagaimana dimaksud pasal 38 ayat (1) berlaku tanpa batas waktu. Pasal ini jelas bertujuan melindungi karya-karya tradisional. Meskipun tujuan dari pasal 60 ayat (1) ini adalah untuk melindungi karyakarya intelektual berupa budaya, adat istiadat maupun nilai-nilai 
budaya yang terkandung dalam masyarakat asli, akan sulit bagi masyarakat tradisional untuk menggunakannya dalam melindungi karya-karyanya. Hal ini disebabkan oleh adanya perbedaan karakter antara Hak Kekayaan Intelektual dan EBT yang membuat sistem hukum Kekayaan Intelektual belum mampu melindungi EBT secara utuh.

Dalam konsep Hak Kekayaan Intelektual khususnya dalam UUHC, pemberian perlindungan terhadap EBT berbeda dengan pemberian perlindungan pada jenis hak cipta lain seperti buku, lagu, ataupun lukisan. Hal ini dikarenakan terhadap EBT tersebut kepemilikannya bukan bersifat individu seperti halnya pada karya cipta buku, lagu, ataupun lukisan tersebut. Namun, kepemilikan EBT tersebut merupakan kepemilikan secara komunal. Artinya EBT dimiliki oleh sekelompok masyarakat adat pada suatu daerah atau tempat tertentu. Selain itu, pencipta Hak Kekayaan Intelektual teridentifikasi secara jelas dan orientasi ciptaannya lebih mengarah kedalam motif ekonomi (mencari keuntungan), sedangkan dalam EBT, identifikasi pencipta asli tidak diketahui karena kemunculannya merupakan suatu budaya yang muncul dari tradisi lisan yang diwariskan secara turun menurun. ${ }^{9}$

Perlindungan terhadap EBT, dengan melihat pada ciri-ciri yang melekat pada EBT tersebut yang sangat berbeda dengan rezim Hak Kekayaan Intelektual umumnya seperti hak cipta buku, lagu, ataupun lukisan yang sangat bersifat individualistik. Sehingga komponen perlindungan yang tepat untuk diberlakukan pada EBT perlu dibedakan dengan jenis Hak Kekayaan Intelektual

9 Dyah Permata Budi Asri, 2018, Perlindungan Hukum Preventif Terhadap Ekspresi Budaya Tradisional di Daerah Istimewa Yogyakarta Berdasarkan Undang-Undang Nomor 28 Tahun 2014 Tentang Hak Cipta, Journal of Intellectual Property Vol. 1 No. 1 Tahun 2018, Fakultas Hukum Universitas Janabadra, Yogyakarta, h. 17. 
umumnya. Sehingga diperlukan upaya perlindungan hukum yang bersifat preventif dan represif.

Perlindungan hukum adalah suatu perlindungan yang diberikan terhadap subyek hukum dalam bentuk perangkat hukum baik yang bersifat preventif maupun yang bersifat represif. Perlindungan Hukum Preventif adalah perlindungan yang diberikan oleh pemerintah dengan tujuan untuk mencegah sebelum terjadinya pelanggaran. Hal ini terdapat dalam peraturan perundang-undangan dengan maksud untuk mencegah suatu pelanggaran serta memberikan rambu-rambu atau batasanbatasan dalam melakukan suatu kewajiban. Perlindungan Hukum Represif merupakan perlindungan akhir berupa sanksi seperti denda, penjara, dan hukuman tambahan yang diberikan apabila sudah terjadi sengketa atau telah dilakukan suatu pelanggaran. ${ }^{10}$ Dengan kata lain, perlindungan hukum merupakan suatu gambaran dari fungsi hukum, yaitu konsep dimana hukum dapat memberikan suatu keadilan, ketertiban, kepastian, kemanfaatan, dan kedamaian.

Perlindungan preventif dari Ekspresi Budaya Tradisional di Indonesia terdapat dalam Undang-Undang Nomor 28 Tahun 2014 tentang Hak Cipta (UUHC), dimana diatur mengenai ketentuan tentang EBT khususnya pada pasal 38. Negara sebagai pemegang Hak Cipta atas EBT, mengatur terhadap aspek perlindungan dari EBT tersebut dengan melakukan kewajiban-kewajiban yang melekat pada negara untuk menginventarisasi, menjaga, dan memelihara terhadap berbagai macam EBT di Indonesia.

Kendatipun demikian, instrumen hukum ini belum mampu untuk memberikan perlindungan hukum yang optimal terhadap

10 Philipus M. Hadjon, 1987, Perlindungan Hukum Bagi Rakyat Indonesia, Bina Ilmu, Surabaya, h.2. 
keberadaan EBT. Sebab, UUHC ini masih mengalami kendala dalam implementasinya, seperti halnya dalam ketentuan pasal 28 ayat (4) UUHC yang menerangkan bahwa "ketentuan lebih lanjut mengenai Hak Cipta yang dipegang oleh Negara atas ekspresi budaya tradisional akan diatur lebih lanjut dengan Peraturan Pemerintah" namun, hingga saat ini belum ada peraturan pemerintah yang mengatur tentang keberadaan EBT secara mengkhusus. ${ }^{11}$

Hal ini menunjukkan perlindungan hukum terhadap kekayaan intelektual masyarakat asli tradisional belum maksimal, sehingga menyebabkan potensi yang seharusnya dimiliki secara penuh oleh Negara Indonesia, kerap dimanfaatkan oleh pihak asing secara tidak sah. Seperti Negara Malaysia yang mengklaim tarian Reog Ponorogo sebagai warisan budaya mereka hingga kasus pendaftaran tari tor-tor yang hendak dilakukan oleh Negara Malaysia.12 Dengan adanya kasus-kasus tersebut, sudah seyogyanya pemerintah dapat menjadikan hal tersebut sebagai suatu pembelajaran untuk melindungi keberadaan EBT serta segera membenahi keberlangsungan perlindungan hukumnya.

\subsubsection{Penguasaan Hak Cipta yang Dipegang Oleh Negara Terhadap Ekspresi Budaya Tradisional}

Sebagaimana yang diatur dalam pasal 38 UUHC bahwa Negara memegang hak cipta atas EBT. Pengambilalihan hak cipta ini dilakukan dengan mekanisme otomatis yang dilakukan secara langsung oleh Negara tanpa kemudian membicarakannya dengan masyarakat adat terlebih dahulu. Hal ini memberikan kesan

11 Ibid, h.3.

12 Djibril Muhammad dan Erdy Nasrul, 2012, "Kronologi Klaim Tari Tor-Tor Versi Malaysia", URL : h t t p : / / n a s i o n a 1.r e p u b lik a . c o. i d / b e r i t a/nasional/umum/12/06/20/m5wstu-kronologi-klaim-taritortor-versi-malaysia. diakses tanggal 17 Februari 2018. 
bahwa perlindungan yang diberikan hanya terfokus pada perlindungan EBT saja dan mengesampingkan kedudukan masyarakat adat sebagai pihak yang secara kontinu melestarikan EBT.

Didalam UUHC tidak ada rumusan sama sekali mengenai keberadaan masyarakat adat dalam perlindungannya. Sebagai contoh, selama ini belum ada konsep dalam undang-undang ini yang mengatur mengenai pengaturan pembagian keuntungan ekonomi antara Negara dengan masyarakat adat ketika kebudayaan yang dikuasai oleh Negara tersebut memperoleh keuntungan ekonomi. Padahal hal tersebut merupakan suatu upaya untuk menjamin hak-hak masyarakat adat. Maka dari itu, kedudukan masyarakat adat sangat perlu untuk mendapatkan pengaturan mengenai EBT. Beberapa peraturan berikut mengatur mengenai pengakuan Negara atas kedudukan masyarakat adat yaitu dalam ketentuan pasal $28 \mathrm{C}$ ayat (1), pasal 28 I ayat (3), pasal 32 ayat (1) UUD NRI 1945, Pasal 23 ayat (2) UU No.18 Tahun 2002 tentang Sistem Nasional Penelitian, Pengembangan dan Penerapan Ilmu Pengetahuan dan Teknologi, UU No. 11 Tahun 2005 tentang Pengesahan Konvenan Internasional tentang HakHak Ekonomi, Sosial, dan Budaya, serta pasal 31 ICESCR (International Convenant on Economic, Social and Cultural Rights).

Permasalahan lain yang kemudian muncul terkait dengan hak cipta atas EBT yang dipegang oleh Negara ini adalah belum adanya lembaga pelaksana sebagai representasi dari kata "Negara" yang terdapat dalam rumusan pasal 38 UUHC. Selama ini belum ada suatu lembaga pelaksana yang sah untuk melaksanakan segala hal yang berkaitan dengan pengaturan EBT. UUHC masih sangat abstrak menyebutkan kata Negara tanpa memberikan penjelasan siapa yang secara sah mempunyai kewenangan dalam 
menjalankan pengaturan mengenai masalah perlindungan EBT ini. Apabila ketentuan pasal 38 dicermati, maka akan tampak bahwa lembaga pelaksana yang berwenang untuk menetapkan suatu ciptaan sebagai EBT tidak ada. Begitupun halnya dalam penjelasan pasal 38 UUHC tidak memberikan keterangan lebih lanjut mengenai makna "Negara" yang tentunya akan sangat berguna untuk penegakan hukum yang semakin kompleks. ${ }^{13}$

Oleh karena Negara adalah entitas yang abstrak, untuk melaksanakan kewenangannya yang lebih konkrit, maka kata Negara dalam pasal 38 UUHC harus dijabarkan lebih lanjut dengan menyebut instansi pemerintah yang mengemban tanggung jawab tersebut. Dengan kondisi yang ada saat ini, maka menjadi tidak jelas, apakah hanya Ditjen HKI yang berwenang untuk mengadministrasikan EBT, atau lembaga-lembaga lain juga berwenang. Hal ini sangat penting untuk diatasi mengingat perlindungan EBT dapat berkaitan dengan instansi pemerintah seperti Departemen Hukum dan HAM, Departemen Kebudayaan dan Pariwisata, Departemen Perindustrian, dan Pemerintah Daerah.

\section{PENUTUP}

\subsection{Simpulan}

1. Pengaturan perlindungan hukum EBT dengan hak cipta di Indonesia masih lemah, karena pada EBT tidak diketahui penciptanya, sedangkan pada karya hak cipta mengharuskan nama pencipta tertera di karya cipta. Oleh karena itu, dalam melindungi EBT diperlukan bentuk perlindungan hukum yang bersifat preventif dan represif.

13 Rahmi Jened Parinduri Nasution, 2013, Interface Hukum Kekayaan Intelektual dan Hukum Persaingan (Penyalahgunaan HKI), PT. RajaGrafindo Persada, Jakarta, h. 87. 
2. Penguasaan hak cipta yang dipegang oleh Negara terhadap EBT sebagaimana yang terdapat dalam ketentuan pasal 38 UUHC dilakukan dengan mekanisme otomatis yang dilakukan secara langsung oleh Negara tanpa kemudian membicarakannya dengan masyarakat adat terlebih dahulu. Disamping itu, mengenai kata Negara yang terdapat didalamnya belum memberikan rumusan yang jelas. Hal ini menunjukkan definisi Negara yang abstrak sehingga untuk melaksanakan kewenangannya yang lebih konkrit, maka kata Negara dalam pasal 38 UUHC harus dijabarkan lebih lanjut dengan menyebut instansi pemerintah yang mengemban tanggung jawab tersebut.

\subsection{Saran}

Dalam upaya memberikan perlindungan hukum terhadap EBT, pemerintah hendaknya segera melakukan identifikasi, inventarisasi dan dokumentasi untuk dicatat ke Kantor Kementerian Hukum dan HAM Direktorat Jenderal HKI. Selain itu, diharapkan pula pemerintah untuk segera merealisasikan Peraturan Pemerintah seperti yang tercantum dalam ketentuan pasal 38 ayat (4) UUHC, kemudian memberikan definisi yang jelas mengenai makna kata Negara yang terdapat dalam pasal 38 UUHC, serta disamping UUHC melindungi keberadaan EBT hendaknya UUHC juga memberikan ruang perlindungan hukum terhadap kedudukan masyarakat adat sebagai pemilik EBT agar hak yang dimiliki oleh masyarakat adat terlindungi dengan maksimal. 


\section{DAFTAR PUSTAKA}

\section{Buku}

Arif Lutviansori, 2010, Hak Cipta dan Perlindungan Folklor di Indonesia, Graha Ilmu, Yogyakarta.

I Gde Pitana Dkk, 1994, Dinamika Masyarakat dan Kebudayaan Bali, BP, Denpasar.

Johny Ibrahim, 2011, Teori dan Metodologi Penelitian Hukum Normatif, Bayu Media, Malang.

M. Munandar Sulaeman, 1995, Imu Budaya Dasar, Suatu Pengantar, PT. Eresco, Jakarta.

Ni Ketut Supasti Dharmawan Dkk, 2017, Hak Kekayaan Intelektual (HKI), Deepublish, Yogyakarta.

Philipus M. Hadjon, 1987, Perlindungan Hukum Bagi Rakyat Indonesia, Bina Ilmu, Surabaya.

Rahmi Jened Parinduri Nasution, 2013, Interface Hukum Kekayaan Intelektual dan Hukum Persaingan (Penyalahgunaan HKI), PT. RajaGrafindo Persada, Jakarta.

\section{Jurnal Ilmiah}

Dyah Permata Budi Asri, 2018, Perlindungan Hukum Preventif Terhadap Ekspresi Budaya Tradisional di Daerah Istimewa Yogyakarta Berdasarkan Undang-Undang Nomor 28 Tahun 2014 Tentang Hak Cipta, Journal of Intellectual Property Vol. 1 No. 1 Tahun 2018, Fakultas Hukum Universitas Janabadra, Yogyakarta.

Ida Ayu Sukihana, I Gede Agus Kurniawan, 2018, Karya Cipta Ekspresi Budaya Tradisional: Studi Empiris Perlindungan Tari Tradisional Bali di Kabupaten Bangli, Jurnal Magister Hukum Udayana, Vol.7 No.1 Mei 2018, Denpasar.

International Law in News, Berebut Hasil Kreasi Pengrajin Perak Bali, Jurnal Hukum Internasional, Volume 6 Nomor 1 Oktober 2008. 


\section{Internet}

Djibril Muhammad dan Erdy Nasrul, 2012, "Kronologi Klaim Tari Tor-Tor Versi Malaysia", URL: http://nasional.re publika.co.id/berita/nasional/umum/12/06/20/m5wstukronologi-klaim-tari-tortor-versi-malaysia. diakses tanggal 17 Februari 2018.

Kompas.com, 2008, "Weleh... Perajin Bali Malah Dituding Menjiplak",URL: https://nasional.kompas.com/read/2008/0 9/12/14474846/weleh.perajin.bali.malah.dituding.menjipla $\underline{\mathrm{k}}$, diakses tanggal 27 Oktober 2018.

\section{Peraturan Perundang - Undangan}

Undang - Undang Dasar Negara Republik Indonesia 1945

Undang - Undang Nomor 28 Tahun 2014 Tentang Hak Cipta

Undang - Undang Nomor 18 Tahun 2002 tentang Sistem Nasional Penelitian, Pengembangan dan Penerapan Ilmu Pengetahuan dan Teknologi

Undang - Undang Nomor 11 Tahun 2005 tentang Pengesahan Konvenan Internasional tentang Hak-Hak Ekonomi, Sosial, dan Budaya 